\title{
Pengembangan Perkampungan Budaya Betawi Dari Condet ke Srengseng Sawah
}

\author{
Rakhmat Hidayat \\ Jurusan Sosiologi Fakultas Ilmu Sosial Universitas Negeri Jakarta (UNJ)
}

\begin{abstract}
Abtsrak: Penelitian ini ingin menjelaskan perubahan sosial yang mengakibatkan dipindahkannyanya Cagar Budaya Betawi dari Condet ke Srengseng Sawah. Menggunakan perspektif perubahan sosial, dengan jelas tergambarkan bahwa Condet mengalami transformasi sosial, ekonomi dan kebudayaan. Perubahan sosial yang terjadi di Condet tidak bisa dilepaskan dari struktur Jakarta sebagai pusat kekuasaan. Srengseng Sawah merupakan kawasan yang masih terjaga lingkungannya, yaitu lingkungan yang sejuk, asri dan cukup rindang dengan pepohonan. Daerah ini dipilih sebagai perkampungan budaya Betawi karena masih memiliki budaya Betawi sebagai ciri khasnya. Hal tersebut ditandai dengan masih bertahannya rumah-rumah panggung berarsitektur khas Betawi. Selain itu, masih bertahan juga makanan khas maupun aksesoris khas Betawi. Faktor lainnya karena Srengseng Sawah dianggap memiliki potensi untuk mengembangan pariwisata budaya (cultural tourism).
\end{abstract}

Kata Kunci: Komunitas Betawi, Kebudayaan, Perubahan Sosial, Urbanisasi.

\begin{abstract}
Abtsract: This study will explain the social changes as a resulted of moved Betawi Cultural Area to Srengseng Sawah. By using the perspective of social change, clearly reflected that Condet transformed the social, economic and cultural. Social changes in Condet not be separated from the structure of Jakarta as a center of power. Srengseng Sawah is the area that still maintained its environment, a cool environment, beautiful and quite shady with trees. Srengseng Sawah chosen as the Township Betawi of Culture because they still have the Betawi culture as his trademark. It is characterized by the persistence of the homes still using typical stage Betawi. Also, still survive Betawi's food and many accessories of Betawi. Other factors because Srengseng Sawah is considered to have potential to develop cultural tourism.
\end{abstract}

Keywords: Betawi Culture, Culture, Social Change, Urbanization

\section{Pendahuluan}

Dalam pembangunan Jakarta, Condet selalu menjadi bahan pembicaraan yang selalu menarik untuk dikaji dari berbagai aspek. Pertama, pembicaraan tentang Condet selalu menarik pada saat DKI Jakarta memiliki Gubernur baru, yaitu komitmen dan konsen setiap Gubernur DKI baru terhadap Condet. Kedua, di kalangan aktivis dan pengamat lingkungan, Condet selalu menarik untuk dikaji seiring dengan berbagai problem lingkungan yang belakangan sering terjadi di Condet, misalnya Kali Ciliwung yang semakin kotor maupun banjir yang sering terjadi di beberapa kawasan di Condet. Ketiga, dalam konteks sosiokultural, Condet merupakan representasi dari transformasi sosio-kultural yang berlangsung lama dan semakin menunjukkan adanya ketimpangan di masyarakat Condet. Dalam konteks itulah tulisan ini ingin menjelaskan hendak mengkaji perubahan social dibalik dipindahkannya perkampungan budaya Betawi dari Condet ke ke Srengseng Sawah. Perpindahan ini tentu saja terkandung berbagai aspek yang tidak dapat dipisahkan dari perubahan sosial yang terjadi di Condet.

Sebagai bagian yang terintegrasi dari struktur sosial, politik dan ekonomi Jakarta, Condet menjadi keniscayaan ketika harus terkorporasi dalam pembangunan Jakarta. Pertumbuhan ekonomi berlangsung secara cepat di Jakarta. Sebagai kota yang mewakili kota-kota besar di belahan dunia, pertumbuhan ekonomi dilihat dengan beberapa indikator seperti industrialisasi dan komersialisasi di kota-kota besar. Implikasinya, 
adalah terjadi urbanisasi (Evers, 1986).

Pertumbuhan ekonomi tidak dapat dirasakan oleh seluruh warga kota-kota besar, dalam hal ini termasuk warga Jakarta. Realitas yang terjadi memang menunjukkan dualisme. Studi McGee (1971) tampaknya mendukung tesis tersebut. Analisa Mc Gee menjelaskan adanya dua kecenderungan yang menjadi ciri khas di negaranegara berkembang. Pertama, kota-kota di negara berkembang telah membesar secara sangat mengesankan. Kedua, pertumbuhan kota di negara-negara berkembang tidak disertai dengan tingkat pertumbuhan ekonomi yang memadai guna memberikan kesempatan kerja bagi penduduknya yang tumbuh dengan cepat yang disertai dengan migrasi.

Kenyataan menunjukkan bahwa saat ini Jakarta diserbu oleh para pendatang pribumi dan mancanegara yang bermigrasi ke Jakarta. Fenomena ini oleh Evers (1986:56) disebut dengan 'transplosi', yaitu suatu perluasan mendadak dari masyarakat kota yang memiliki andil merombak citra kota dan masyarakat secara besar-besaran. Namun demikian, membludaknya kaum pendatang yang membanjiri Jakarta harus dibayar mahal. Pasalnya, komunitas Betawi sebagai kelompok masyarakat asli Jakarta eksistensinya kian terancam. Perlahan-lahan, komunitas Betawi terus menurun drastis. Tuntutan pembangunan kota Jakarta menyebabkan semakin tergusurnya kawasan-kawasan yang selama ini dikenal dengan kawasan Betawi asli.

Untuk mempertahankan komunitas Betawi asli ditetapkanlah Condet sebagai kawasan perkampungan Betawi pada masa kepemimpinan Ali Sadikin sebagai Gubernur DKI Jakarta. Keputusan tersebut dituangkan melalui SK No DI7903/a/30/1975. Hal ini beralasan mengingat Condet dikenal sebagai penghasil buah-buahan seperti duku dan salak. Bahkan, sebelum duku Palembang ada, duku Condet dikirim ke seluruh pelosok tanah air termasuk Palembang.

Dalam perjalanannya, Condet terus mengalami perubahan. Berbagai macam perubahan baik sosial, budaya maupun ekonomi terjadi di daerah ini. Faktor lain yang berpengaruh juga adalah kebijakan pemerintah DKI Jakarta terhadap wilayah Condet. Salah satunya adalah kebijakan dipindahkannya kawasan perkam- pungan Betawi dipindahkan ke Setu Babakan, Kawasan Srengseng Sawah, Jagakarsa, Jakarta Selatan pada saat Sutiyoso menjadi Gubernur DKI Jakarta. Dalam konteks inilah, menarik untuk mengkaji lebih mendalam pemilihan Setu Babakan sebagai perkampungan Betawi. Dipertahankannya komunitas Betawi merupakan upaya berkesinambungan dalam mempertahankan komunitas lokal dalam pembangunan yang berlangsung di Jakarta. Komunitas Betawi dalam konteks sosio-historis memiliki peran penting yang tidak dapat diabaikan kontribusinya.

Permasalahan penelitian dijabarkan dalam pertanyaan-pertanyaan berikut ini: 1) Bagaimana perubahan sosial yang terjadi di Condet yang mengakibatkan tidak dilanjutkannnya perkampungan budaya Betawi? dan 2) Apakah yang menyebabkan kawasan Srengseng Sawah dipilih menjadi kawasan Perkampungan Budaya Betawi?

Berdasarkan permasalahan maka penelitian ini bertujuan untuk mengetahui: 1) perubahan sosial yang terjadi di Condet yang mengakibatkan dipindahnya perkampungan budaya Betawi ke Srengseng Sawah dan 2) faktor-faktor yang menyebabkan dipindahkannya perkampungan budaya Betawi dari Condet ke Srengseng Sawah, Jakarta Selatan.

\section{Kajian Literatur Definisi Perubahan Sosial}

Perubahan sosial merupakan gejala perubahan dari suatu keadaan sosial tertentu ke keadaan sosial lain. Karena itu perubahan sosial pasti memiliki suatu arah dan tujuan tertentu. Perubahan sosial dapat suatu kemajuan (progress) atau sebaliknya dapat berupa suatu kemunduran (regress). Perubahan-perubahan yang terjadi dalam masyarakat menimbulkan kesesuaian antara unsur-unsur sosial yang ada dalam masyarakat. Dengan kata lain, perubahanperubahan sosial akan mengubah struktur dan fungsi dari unsur-unsur sosial dalam masyarakat. Dengan demikian, perubahan sosial dalam masyarakat mengandung pengertian ketidaksesuaian diantara unsur-unsur sosial yang saling berbeda dalam masyarakat sehingga menghasilkan suatu pola kehidupan yang tidak serasi fungsinya bagi masyarakat yang bersangkutan. 
Kingsley Davis dalam (Sztompka, 2005:56) mendefinisikan perubahan sosial sebagai perubahan-perubahan yang terjadi pada struktur dan fungsi masyarakat. Definisi ini dapat ditegaskan bahwa dalam perubahan sosial dan sistem sosialnya. Struktur sosial merupakan bentuk jalinan jaringan hubungan antarindividu dalam masyarakat dimana terjalin interaksi, interealism dan komunikasi sosial. Sedangkan sistem sosial menunjuk pada bagaimana hubungan antara unsur-unsur sosial dalam masyarakat sehingga membentuk kebulatan yang berfungsi.

\section{Definisi Kota}

Sejak abad ke-19, persoalan yang dihadapi kota Jakarta adalah masalah pertambahan penduduk. Pada saat itu bertambahnya penduduk Jakarta lebih disebabkan oleh banyaknya orang-orang Belanda berdatangan ke Indonesia (Saidi, 1996:350, Syuaib, 1996:366). Persoalan pertambahan penduduk hanyalah salah satu dampak yang dihadapi oleh sebuah kota. Hal yang sama sebenarnya dialami oleh berbagai kota di negera-negara dunia ketiga.

Menurut Harris and Ullman dalam Nas (1979) menjelaskan kota sebagai fenomena yang paradoks. Pertumbuhannya yang cepat dan luasnya kota-kota menunjukkan cara yang unggul untuk mengeksploitasi bumi. Tetapi di lain pihak, justru berkat sukses eksploitasi ini yang berakibat meluasnya daerah, ternyata kota-kota malahan merupakan suatu lingkungan yang miskin bagi manusia.

Dengan demikian kota menjadi istilah sentral dalam penelitian ini. Ada berbagai definisi tentang kota dari berbagai tokoh. Menurut David dan Jary (1991), kota dijelaskan sebagai :

"an inhabited placxe which is differentiated from a town or village by its greater size and by the range of activities practiced within its boundaries, usually religious, military political, economic, educational and cultural".

Secara bebas, kota dapat didefinisikan sebagai kawasan hunian yang relatif besar, sehingga dapat dibedakan dengan kampung atau kota kecil, serta terdapat aktivitas yang relatif beragam di bidang ekonomi, kebudayaan, keagamaan, pendidikan, dan politik.
Definisi kota juga mendapat perhatian besar dari beberapa tokoh sosiologi klasik seperti Durkheim, Weber, Marx (Saunders, 1989:13). Durkheim melihat kota sebagai hunian masyarakat yang ditandai oleh solidaritas organik, yaitu suatu ikatan yang muncul karena adanya differensiasi (perbedaan) pekerjaan atau division of labour para penghuninya. Senada dengan Durkheim, Marx (Saunders, 1989:15, Susser, 2002:45) menganggap kota sebagai hunian manusia yang ditandai oleh bentuk yang paling nyata dari mode of production kapitalis. Banyaknya pabrik milik kaum borjouis, kaum proletar yang bekerja di pabrik, dan pola hubungan kaum proletar dengan borjuis yang eksploitatif, merupakan sebagian ciri suatu kegiatan sosial ekonomi kapitalis yang tumbuh di kota.

\section{Definisi Urbanisasi}

Pertumbuhan Jakarta seperti yang terjadi saat ini sebenarnya tak dapat dipisahkan dari fenomena urbanisasi. Urbanisasi dapat dipahami sebagai proses pembentukan kota, yaitu suatu proses yang digerakkan oleh perubahan-perubahan struktural dalam masyarakat sehingga daerahdaerah yang dulu merupakan daerah pedesaan dengan struktur mata pencarian yang agraris maupun sifat kehidupan masyarakatnya lambat laun atau melalui proses yang mendadak memperoleh sifat kehidupan kota (Nas, 1979:42).

Urbanisasi merupakan salah satu proses yang tercepat di antara perubahan-perubahan sosial di seluruh dunia. Tidak salah jika urbanisasi merupakan pra kondisi untuk modernisasi dan pembangunan (Evers, 1986:49). Raharjo (1983:60) menekankan pengertian urbanisasi tidak jauh berbeda dengan konsep akulturasi, diffusi, asimilasi dan amalgasi. Proses urbanisasi tidak hanya proses diffusi kebudayaan kota ke desa, tetapi juga terhadap masyarakat kota itu sendiri.

Hal itu pula yang terjadi pada masyarakat Betawi yang semakin memudar baik dari segi eksistensinya maupun kebudayaannya. Melonjaknya urbanisasi di perkotaan berakibat lebih luas lagi, akibatnya terjadi apa yang disebut sebagai urbanisasi berlebih (overurbanization) yaitu suatu keadaan tidak mampunya kota-kota menyediakan fasilitas pelayanan pokok dan 
kesempatan kerja yang memadai untuk penduduk yang bertambah dengan pesat (Manning dan Effendi, 1996:8)

Konsep overurbanized pertama kali diungkapkan oleh K. Davis dan H. Herz Golden dalam Nas (1979:53). Mereka menyatakan bahwa ada hubungan yang pararel antara tingkat urbanisasi dan tingkat perkembangan ekonomi. Dengan kata lain, persentasi penduduk kota yang sangat besar tidak sesuai dengan perkembangan ekonomi negara dalam hal ini tersedianya lapangan pekerjaan.

Proses pengkotaan di Jakarta juga dipengaruhi oleh kebijakan berdasarkan urban bias yaitu kebijakan-kebijakan yang cenderung mengutamakan kota. Kebijakan ini hanya akan memperlebar jurang pendapatan antara kota dan desa (Schwab, 1992:36). Hal tersebut antara lain dilakukan dengan pembangunan pusat-pusat komersil (seperti mal, apartemen, hotel, lapangan golf, dan sebagainya) secara gencar di wilayah perkotaan tanpa memperhatikan pengembangan daerah penyangga, dalam hal ini adalah daerahdaerah pedesaan. Risikonya kebijakan tersebut akan terus mendorong tetap berlangsungnya tingkat migrasi yang tinggi meskipun pengangguran di kota (Jakarta) terus meningkat.

\section{Komunitas Betawi}

Komunitas merupakan suatu unit sosial yang penting yang secara sosiologi dapat menjadi penentu keberhasilan pembangunan sosial di perkotaan (Sunarto, 2000:133). Komunitas juga merupakan sekelompok orang yang tinggal dan menetap bersama dalam suatu wilayah tertentu dengan ciri-ciri sebagian besar warganya terdiri atas orang Betawi. Definisi ini menunjukkan bahwa community atau masyarakat setempat merupakan kelompok-kelompok atau kesatuan-kesatuan atas dasar wilayah yang tidak mempunyai kepentingankepentingan yang khusus/tertentu (Soekanto, 2002:114).

Istilah komunitas sendiri merupakan salah satu konsep pokok yang sering dijumpai dalam kajian perkotaan. Definisi yang lebih tegas diungkapkan oleh Polin dalam Nas (1979:38) yaitu masyarakat lokal yang dibentuk atas dasar ikatan yang kuat dan memiliki identitas yang sama. Menurut Surjomihardjo (1973) separuh dari penduduk Jakarta pendatang dan separuh sisanya adalah penduduk asli (Betawi). Komunitas Betawi merupakan komunitas yang multi etnik, bahkan keanekaragaman itu telah ada sejak ratusan tahun yang lalu.

Shahab (1994) mengkategorisasikan komunitas Betawi menjadi tiga hal berdasarkan variasi dialek Bahasa Betawi, yaitu Betawi Tengah, Betawi Udik, dan Betawi Pinggir. Dalam konteks yang kebih luas untuk melacak siapa yang disebut sebagai komunitas Betawi dapat menggunakan aspek lainnya misalnya warisan budaya, sejarah dan bahasa. Mengacu pada penjelasan ini, yang dimaksud dengan orang Betawi adalah mereka yang memiliki darah Betawi serta berbahasa dan berbudaya Betawi.

Dilihat dari kesukubangsaan, orang Betawi yang merupakan sebutan bagi penduduk asli dan berdiam di Jakarta memiliki latar belakang sejarah yang telah melewati rentang waktu yang cukup panjang. Lebih kurang 420 tahun yang lalu masyarakat Jakarta atau Betawi dan sekitarnya banyak mengalami perubahan (Alamsyah, et.al, 2004:8). Proses sosial ini adalah hasil pembauran dari berbagai unsur budaya berbagai bangsa dan suku bangsa yang berasal dari berbagai daerah di Indonesia.

Keadaan Jakarta tersebut di atas telah memungkinkan kota ini menjadi arena tempat pembauran bangsa antara berbagai bangsa yang ada di Indonesia dan berbagai bangsa di dunia. Mereka datang dengan berbagai alasan dan berbagai kepentingan. Semua pihak itu datang dengan latar belakang kebudayaan yang beranekaragam. Pembauran itu telah menghasilkan suatu kebudayaan baru bagi penghuni Jakarta yang kemudian dikenal sebagai orang Betawi. Nama Betawi berasal dari kata Batavia sesudah Belanda (Jan Pieterszoon Coen) datang di Indonesia pada tanggal 30 Mei 1619. Dahulu namanya Sunda Kelapa, kemudian berubah menjadi Betawi. Di zaman kemerdekaan Indonesia disebut Jakarta. Jadi sejak tahun 1527 sampai proklamasi kemerdekaan Indonesia, Jakarta telah mengalami beberapa kali perubahan nama dari Sunda Kelapa menjadi Jakarta (Alamsyah, et.al, 2004:8). 


\section{Definisi Perkampungan Budaya Betawi}

Perkampungan Budaya Betawi merupakan sebuah tempat dimana dijadikan sebagai kawasan terpadu pelestarian dan pengembangan budaya Betawi. Di tempat ini seluruh kehidupan didesain dalam suasana budaya Betawi, mulai dari rumah, bahasa maupun berbagai acara kesenian. Berdasarkan Peraturan Daerah Provinsi DKI Jakarta Nomor 3 Tahun 2005 tentang Penetapan Perkampungan Budaya Betawi di Kelurahan Srengseng Sawah, Jakarta Selatan mendefinisikan Perkampungan Budaya Betawi sebagai suatu kawasan di Jakarta dengan komunitas yang ditumbuhkembangkan budaya Betawi yang meliputi seluruh hasil gagasan dan karya baik fisik maupun non fisik yaitu kesenian, adat istiadat, folklor kesastraan dan kebahasaan, kesejarahan serta bangunan yang bercirikan kebetawian.

Jakarta pernah memiliki perkampungan Betawi yaitu Condet. Condet ditetapkan pada era kepemimpinan Ali Sadikin sebagai Gubernur DKI Jakarta, tepatnya tahun 1974. Pemerintah Provinsi DKI Jakarta mengeluarkan Surat Keputusan (SK) Gubernur No D. IV-1511/e/3/74 tanggal 30 April 1974 tentang Penetapan Condet sebagai Pengembangan Kawasan Budaya Betawi. Kemudian disusul SK Gubernur No D.I-7903/a/30/ 75 tanggal 18 Desember 1975, gubernur Ali Sadikin kembali menetapkan Condet sebagai Daerah Buah-buahan.

Namun demikian, dalam perkembangannya lokasi tersebut dipindahkan ke Srengseng Sawah pada tahun 2004. Daerah ini dijadikan Pusat Perkampungan Betawi bersamaan dengan HUT DKI yang ke-474 dikarenakan masih banyaknya perkampungan Betawi asli di daerah ini. Daerah cagar budaya ini meliputi 165 hektar, terdiri dari Kebun Rakyat, perkampungan masyarakat betawi serta kedua danau yang mengapit perkampungan ini.

Masyarakat di wilayah ini mengembangkan usaha pertanian dan perikanan sekaligus membantu dalam usaha penghijauan wilayah Situ Babakan. Selain itu di daerah ini dapat disaksikan pula keseharian masyarakat setempat seperti budidaya ikan dalam keramba yang terdapat di sepanjang pinggiran situ, pemancingan, bercocok tanam, perdagangan, pembuatan kerajinan tangan serta pembuatan makanan khas Betawi seperti dodol Betawi dan Bir pletok. Selain itu di daerah ini juga sering diselenggarakan acara keseniah daerah Betawi seperti Tari Cokek, Tari Topeng, Lenong dan Ondel-ondel pada panggung terbuka setiap hari Sabtu dan Minggu (Alamsyah, et.al, 2004:45). Pada acara ini biasanya pengunjungpun dapat ikut berinteraksi dalam pelaksanaan acara-acara tersebut, seperti ikut menari atau mengomentari para pemain lenong yang sedang beraksi.

\section{Definisi Budaya dan Budaya Betawi}

Kebudayaan (culture) adalah produk dari seluruh rangkaian proses social yang dijalankan oleh manusia dalam masyarakat degan segala aktivitasnya. Dengan demikian, maka kebudayaan adalah hasil nyata dari sebuah proses yang dijalankan oleh manusia bersama masyarakatnya. Menurut Koentjaraningrat (1997), culture mempunyai kesamaan arti dengan kebudayaan yang artinya mengolah atau mengerjakan yaitu mengolah tanah atau bertani. Culture diartikan sebagai segala daya dan kegiatan manusia untuk mengolah dan mengubah alam.

Menurut Selo Soemarjan dan Soelaeman Soemardi bahwa kebudayaan sebagai semua hasil karya, rasa, dan cipta masyarakat. Sedangkan E.B Taylor mengemukakan bahwa kebudayaan merupakan totalitas pengalaman manusia yang mencakup pengetahuan, kepercayaan, kesenian, moral, hukum, adat istiadat dan kapabilitas serta kebiasaan-kebiasaan lain yang dimiliki oleh manusia sebagai anggota masyarakat.

C Kluckholn menghimpun dan menerbitkan kembali 164 definisi kebudayaan yang dikelompokan menjadi enam: deskriptiif, historical, normatif, psikologis, struktural, dan genetik (Saifuddin, 2006 : 83). Melalui Universal Categories of Culture, Kluckholn merumuskan 7 unsur kebudayaan yang universal, yaitu: a) Sistem Teknologi yaitu peralatan dan perlengkapan hidup manusia; b) Sistem mata pencaharian hidup dan system-sistem ekonomi (pertanian, peternakan, system produksi, dan lainnya); c) Sistem kemasyarakatan (kekerabatan, organisasi politik, dII); d) Bahasa (lisan dan tulisan); e) Kesenian (seni rupa, sauara, gerak, dsb); f) Sistem pengetahuan; dan g) Religi (Sistem kepercayaan)

Sedangkan Melvile J Herrsovits (Soekanto, 2002:175) mengajukan 4 unsur pokok kebu- 
dayaan yakni: 1) Alat-alat teknologi; 2) Sistem ekonomi; 3) Keluarga; dan 4) Kekuasaan Politik.

\section{Metodologi Penelitian \\ Pendekatan Penelitian}

Penelitian ini dilakukan dengan pendekatan kualitatif (Travers, 2001:9-10; Newman, 1994:62). Pendekatan kualitatif memfokuskan telaahnya pada makna-makna subyektif, pengertianpengertian, metafor-metafor, simbol-simbol, dan deskripsi-deskripsi ihwal suatu kasus spesifik yang hendak diteliti. Pendekatan ini dipilih agar studi ini memperoleh gambaran detail dan mendalam informasi mengenai suatu gejala sosial tertentu yang bersifat fenomenologis. Dalam studi, pendekatan kualitatif berupaya mendapatkan penjelasan yang mendalam tentang dipilihnya Srengseng Sawah sebagai Perkampungan Budaya Betawi.

Penelitian ini berusaha memperoleh kejelasan mengenai perubahan sosial yang terjadi di Condet yang menyebabkan terjadi perpindahan pengembangan perkampungan budaya Betawi ke Srengseng Sawah, Jakarta Selatan. Oleh karena itu, pendekatan kualitatif relevan digunakan dalam penelitian ini karena bertujuan untuk memperoleh pemahaman (insight) yang menyeluruh (whole) dan tuntas (exhaustive) mengenai strukturstruktur yang ada.

\section{Teknik Pengumpulan Data}

Dalam penelitian ini teknik pengumpulan data yang digunakan meliputi: 1) Studi pustaka yang dilakukan sejak penyusunan proposal sampai dengan laporan hasil penelitian. Teknik ini merupakan data primer dalam menganalisa tema yang dibahas. Berbagai pustaka yang akan dianalisa dalam studi ini yaitu hasil penelitian yang berhubungan dengan Condet dan komunitas Betawi. Selain itu, data sekunder juga meliputi gambaran umum mengenai Condet dan Srengseng Sawah seperti keadaan geografi dan demografi, struktur okupasi, dan sebagainya; 2) Observasi dilakukan dengan cara pengamatan secara terbuka yaitu mengamati berbagai gejala, perilaku, perubahan fisik yang terjadi di (masyarakat) Condet dan Srengseng Sawah; dan 3) Wawancara dilakukan dengan beberapa masyarakat dan tokoh masyarakat di Condet maupun Srengseng Sawah.

\section{Lokasi Penelitian}

Penelitian ini dilakukan di Kelurahan Srengseng Sawah, Kecamatan Jagakarsa, Jakarta Selatan yang sudah dijadikan sebagai Perkampungan Budaya Betawi. Namun demikian untuk menjawab pertanyaan penelitian, lokasi penelitian juga dilakukan di kawasan Condet khususnya di Kelurahan Bale Kambang, Jakarta Timur. Dipilihnya Kelurahan Bale Kambang karena sejak Condet dijadikan cagar budaya pada saat Ali Sadikin menjadi Gubernur merupakan pusat kawasan cagar budaya dan cagar buah-buahan khas Jakarta. Hal dimaksudkan untuk menjelaskan dipindahkannya perkampungan budaya Betawi dari Condet ke Srengseng Sawah. Penelitian ini berlangsung sejak bulan Desember 2005 hingga Februari 2006. Penelitian di lapangan dilakukan selama dua bulan mulai Desember 2005 hingga Januari 2006. Proses penulisan laporan penelitian berlangsung selama Februari 2006

\section{Hasil Penelitian dan Pembahasan Perubahan Sosial di Condet}

Saat ini Condet mengalami perubahan sosial yang sangat dinamis dalam berbagai aspek. Condet yang dulu berbeda dengan Condet hari ini. Pada tahun 1970-an Condet memiliki berbagai prestasi dan sejarah yang khas. Secara fisik, Condet sudah berubah. Salah satu yang masih bertahan adalah beberapa tokoh masyarakat Condet yang masih hidup yang sempat menjadi saksi bagaimana Condet dijadikan sebagai cagar budaya dan cagar buah-buahan.

Condet yang ditetapkan Gubernur Ali Sadikin sebagai cagar budaya dan cagar buah-buahan sejak 1978 boleh dikata gagal. Warga Betawi yang dahulu mayoritas di Kawasan Kramat jati, Jakarta Timur, sudah banyak yang pindah atau makin terdesak ke pinggiran. Sementara kebun dan pepohonan rindang yang dulunya boleh dikata tidak tertembus sinar matahari karena rimbunnya, kini berganti menjadi rumah-rumah, kontrakan dan tempat-tempat perkantoran Pusat Jasa Tenaga Kerja Indonesia (PJTKI).

Pada saat Condet dijadikan cagar buahbuahan, setiap kepala keluarga pasti memiliki lahan untuk menanam buah duku atau buah salak. 
Menurut salah satu informan penelitian, Haji Mat Zakap (72 tahun) yang peneliti wawancarai mengatakan bahwa setiap warga yang memiliki rumah 500 meter persegi, tanah tersebut dialokasikan 100 meter persegi untuk bangunan rumah sisanya untuk penghijauan di antaranya ditanami pohon buah-buahan seperti salak, duku, melinjo, duren, manggis atau mangga. Tidak salah, jika mengapa Condet dulu dikenal sebagai pemasok buah-buahan terkenal di tanah air khususnya buah duku dan salak karena hampir setiap rumah terdapat pohon buah-buahan.

Ketika Ali Sadikin menjadi Gubernur DKI pada tahun 1966-1977 perhatian terhadap Condet boleh dikata sangat besar. Hal itu dibuktikan tersedianya anggaran untuk melestarikan budaya Betawi di Condet. Setiap rumah Betawi diberi dana rehabilitasi dan pemeliharaan terutama untuk lantai dasar rumahnya sebesar Rp 30.000 per bulan. Sayang, pendanaan itu hanya berjalan singkat seiring dengan pergantian gubernur.

Perhatian Ali Sadikin untuk mempertahankan keaslian (genuine) komunitas Betawi melalui Condet boleh dikatakan sebagai kebijakan yang sangat positif. Padahal, bersamaan Condet ditetapkan sebagai cagar budaya, Jakarta sedang mengalami pembangunan yang gencar, yaitu berlangsung sejak akhir 1960-an dan awal 1970an (Jellinek, 1984:1-2). Studi Jellinek menggambarkan terjadinya simbiotis antara kampung dan kota. Menurutnya, berbagai kekuatan perubahan di Jakarta terus bergerak dengan cepat seiring dengan modernisasi yang justru mengancam keberadaan kampung-kampung. Apalagi, kebijakan tersebut dilakukan dengan penggusuran besar-besaran terhadap kampungkampung kumuh yang dianggap merusak dan mengganggu pembangunan kota. Ali Sadikin tampaknya berupaya mengakomodasi kepentingan lokal dibanding nasional. Asvi Warman Adam dalam Herlambang (2006:x; xii) menyebut orientasi politik yang dilakukan Ali Sadikin dengan istilah 'politik (mikro) kota'. Bahkan, Asvi membandingkan Ali Sadikin dengan MH Thamrin yang mengembangkan program perbaikan kampung (kampung verbetering)

Condet pasca kepemimpinan Ali Sadikin terus berubah. Pada saat kepemimpinan Gubernur Soeprapto mengeluarkan Instruksi Gubernur DKI
Jakarta Nomor 323 Tahun 1985 tentang penyusunan konsep pelaksanaan daerah Condet sebagai daerah buah-buahan. Pada tahun 1986, terbit Instruksi Gubernur No 19/1986 tentang status quo pengembangan kawasan Condet. Pada tahun yang sama, dikeluarkan Instruksi Gubernur No 227/1986 tentang pencabutan status quo. Isinya agar setiap kegiatan pembangunan disesuaikan dengan konsep pengembangan Condet. Gagal menjadikan Condet sebagai cagar budaya, Sutiyoso menetapkan Srengseng Sawah sebagai Perkampungan Budaya Betawi melalui Perda No 3 Tahun 2005 tentang Penetapan Perkampungan Budaya Betawi di Kelurahan Srengseng Sawah, Kecamatan Jagakarsa, Jakarta Timur. Perda tersebut ditetapkan pada 10 Maret 2005.

Perubahan yang terjadi di Condet, meminjam perspektif Wallerstein dalam Smith dan Feagin (1987:37) mengalami apa yang disebut pheriperalization yaitu transformasi lebih lanjut kehidupan sehari-hari penduduk setempat yang bersifat baru seperti pola pikir, cara berperilaku, perubahan institusi, maupun perubahan pemukiman. Proses peminggiran dan perubahan tersebut sebenarnya tidak dapat dilepaskan dari pengaruh ekonomi global yang terjadi di berbagai kota besar seperti halnya Jakarta. Tambora, Jakarta Barat.

Menurut Alwi Shahab dalam Ramelan (1977) menganalisa pada tahun 1950-an penduduk Pekojan hampir 95 persen masih keturunan Arab. Perlahan-lahan mereka mulai terdesak dengan kehadiran warga pendatang di daerah mereka. Beberapa penduduk Pekojan mulai mencari tempat-tempat yang dianggap lebih nyaman. Daerah-daerah baru tersebut diantaranya adalah Condet, Jatinegara, dan Tanah Abang. Tujuan mereka mencari daerah-daerah tersebut sebenarnya tidak lain untuk mengembangkan usaha bisnis yaitu Penyalur Jasa Tenaga Kerja Indonesia (PJTKI) yang dikelola oleh warga keturunan Arab.

Setelah itu di Condet menjamur kantor-kantor PJTKI yang dilengkapi juga dengan asrama penampungan Tenaga Kerja Indonesia (TKI) dan Tenaga Kerja Wanita (TKW). Kebanyakan TKI dan TKW tersebut berasal dari daerah-daerah Pantai Utara (Pantura) Jawa seperti Subang, Indramayu, 
Karawang, Brebes, Tegal, Pekalongan, Pemalang, dan Cirebon. Mereka banyak diberangkatkan ke negara-negara Timur Tengah seperti Saudi Arabia, Yordania, Mesir, Yaman. Negara-negara tetangga seperti Malaysia, Brunei Darussalam, Singapura juga menjadi incaran para TKW dan TKI. Sebelum berangkat ke negara tujuannya, mereka diharuskan tinggal di tempat penampungan/ asrama yang sudah disediakan oleh penyalurnya selama beberapa bulan atau beberapa minggu untuk dibekali keterampilan maupun bahasa.

Tidak sedikit PJTKI yang mengambil jalan pintas, tanpa memberikan bekal yang cukup kepada TKW dan TKI. Namun demikian dalam sejarah masyarakat Condet, menurut salah seorang warga Bale Kambang yang bernama Dudung, pernah ada satu orang warga Condet yang menjadi TKW ke Arab Saudi menjadi tukang jahit. Dudung yang sehari-hari menjadi tukang ojek dan tinggal di Jalan Munggang, warga Condet yang menjadi TKW tersebut karena terpaksa.

Perubahan Condet juga ditunjukkan dengan tercemarnya kali Ciliwung yang mengaliri kawasan Condet. Hal itu disebabkan karena bermunculan pabrik plastik di sekitar kali Ciliwung. Sampahsampah plastik mencemari kali Ciliwung. Menurut Haji Mat Zakap (72 tahun) pabrik-pabrik plastik itu memproduksi limbah industri yang sulit hancur. Haji Mat Zakap mengatakan :

"Sebelum marak berdiri pabrik-pabrik plastik, warga yang tinggal di bantaran kali Ciliwung sangat nyaman dan diuntungkan dengan keberadaan kali Ciliwung. Dulu, masyarakat sehari-hari menggunakan air kali Ciliwung untuk mandi, minum, dan mencuci pakaian. Sekarang, jik air itu digunakan untuk mandi, dan mencuci pakaian, tangan dan kaki akan gatal-gatal"

Perubahan di Condet juga diperlihatkan dengan semakin menghilangnya rumah-rumahrumah Betawi. Menurut Ramelan (1977:38) yang dimaksud rumah Betawi yang dahulu dikembangkan di Condet adalah rumah yang berlantaikan tanah, berdinding bambu, beratapkan genting, serambi muka terbuka. Pada saat Condet ditetapkan sebagai cagar budaya, Pemerintah DKI Jakarta memberi perhatian khusus kepada rumah Betawi dengan memberikan bantuan dana sebesar Rp 2.000.000 untuk sepuluh rumah yang tua agar direnovasi dan biaya pemeliharaan dengan tidak merubah arsitektur rumah lama (Ramelan, 1977:38).

Kehadiran warga keturunan Arab dari Pekojan ke Condet mengakibatkan berkembangnya sumber ekonomi baru di luar pertanian. Umumnya pergeseran itu dilakukan dengan cara memperluas atau memperbanyak aktivitas ekonomi mereka ke luar usaha tani (off-farm). Warga keturunan Arab yang datang ke Condet tentu saja membutuhkan kantor, asrama/tempat penampungan TKW dan TKI atau juga digunakan sendiri untuk tempat tinggal mereka. Banyak kebun pertanian milik warga dijual kepada warga pendatang. Masyarakat Condet pun banyak yang tergiur menjual tanah dan kebunnya kepada warga keturunan Arab. Salah satu faktor yang menyebabkan itu terjadi karena warga penghasilan yang mereka andalkan dari usaha tani buah-buahan tidak lagi menjanjikan. Akibatnya, perlahan-lahan kebun buah-buahan yang hampir tersedia di setiap rumah mulai berkurang.

Sisi sebaliknya mulai muncul kantor-kantor PJTKI, tempat penampungan TKI dan TKW. Fenomena baru muncul di Condet, mulai berkembang kontrakan dengan model kos-kosan (hanya 1 kamar, kamar mandi terpisah dan digunakan secara kolektif), atau ada juga 'model paviliun', yaitu rumah kecil yang terdiri atas rumah tamu, 1 kamar tidur, dapur dan kamar mandi. Sebagian orang lazim menyebutnya dengan 'rumah petak'. Rumah kontrakan tersebut banyak dimiliki oleh warga Condet yang memanfaatkan kebun buah-buahan yang dimilikinya. Maka tidak heran, saat ini di sepanjang Condet bermunculan kontrakan-kontrakan yang banyak dihuni oleh warga pendatang, sebagian juga oleh karyawankaryawan PJTKI. Satu hal yang tak dapat dipisahkan adalah keberadaan Pusat Grosir Cililitan (PGC) yang baru dibangun beberapa tahun terakhir memberikan pengaruh bagi masyarakat Condet, banyak karyawan-karyawan PGC yang mengontrak di kawasan Condet karena jarak yang tak terlalu jauh dengan tempat kerja mereka. Menjamurnya bisnis kontrakan dan kantor PJTKI tentu saja menyebabkan semakin berkurangnya secara drastis kebun buah-buahan yang selama ini menjadi ciri khas Condet. 
Faktor lain mengapa warga Condet menjual tanahnya kepada warga pendatang adalah karena kemajuan pemikiran masyarakat saat itu. Pada tahun 1980-an, pemikiran warga Condet mulai maju yang ditandai dengan banyaknya warga Condet yang ingin menyekolahkan anaknya minimal SMA. Oleh karena itu, mereka membutuhkan biaya besar, sedangkan hasil pertanian tidak mencukupi. Warga Condet banyak yang menjual tanah ke warga pendatang. Kemajuan pemikiran tidak dapat dipisahkan dari kemampuan pendidikan seseorang. Roda perubahan sosial di Condet tampaknya terus berputar. Macionis seperti dikutip Sztompka (2005:5) mengatakan bahwa perubahan sosial adalah transformasi dalam organisasi masyarakat, dalam pola berpikir dan dalam pola perilaku pada waktu tertentu.

Setelah warga Bale Kambang dan kelurahan lainnya di Condet tidak lagi mengandalkan kebun buah-buahan sebagai sumber pendapatan, mereka kemudian beralih profesi, antara lain di sektor jasa. Padahal pada saat Condet menjadi cagar budaya Betawi sangat dikenal dengan penghasil buah-buahan. Penduduk Condet saat itu hampir 80 persen bermata pencaharian sebagai petani buah-buahan. Di Kelurahan Bale Kambang misalnya, sebagai lokasi dimana penelitian utama dilangsungkan, pada tahun 1970-an mata pencarian masyarakatnya hampir 60 persen petani salak, 20 persen petani buahbuahan, 10 persen karyawan/buruh, 10 persen lain-lain (Ramelan, 1977:38). Ciri khas penghasil buah-buahan yang ada di Condet telah berlangsung sejak lama, bahkan sudah ada sejak leluhur mereka. Selain pohon duku dan salak, Condet juga dikenal penghasil pohon melinjo, yaitu bahan untuk makanan emping.

Saat ini banyak warga Condet yang mengandalkan perekonomian keluarga dari bisnis kontrakan rumah, membuka warung makan, dan warung kelontong yang menjual kebutuhan hidup sehari-hari. Di antara mereka juga tidak sedikit yang menjadi tukang ojek. Di sepanjang kawasan Condet khususnya Bale Kambang selalu ditemukan pangkalan ojek. Menariknya, pangkalan ojek itu tidak hanya ditemukan di setiap perempatan jalan raya, akan tetapi di setiap gang-gang kecil kerap dijumpai pangkalan ojek.
Meskipun jumlah tukang ojek yang ada di ganggang kecil tersebut tak sebanyak dengan pangkalan ojek yang mangkal di pertigaan atau perempatan jalan raya. Saat ini menjadi tukang ojek menjadi pilihan profesi yang relatif tidak sulit, apalagi dengan fasilitas kredit motor yang mudah, setiap orang dapat memiliki motor dengan mudah. Keberadaan tukang ojek di kawasan Bale Kambang khususnya maupun Condet umumnya diuntungkan dengan aktivitas karyawan PJTKI yang merupakan salah satu konsumen utama tukang ojek.

Keterkaitan masyarakat Condet dengan sistem ekonomi di luar pertanian dapat menciptakan sumber-sumber ekonomi baru dan menumbuhkan kesempatan-kesempatan ekonomi baru di daerah yang awalnya berbasiskan pertanian. Perubahan ini kontinu dengan perubahan sosial dan budaya yang terjadi pada masyarakat Condet. Banyak diantara warga Condet yang cenderung konsumtif, dapat dilihat dari kepemilikan peralatan/perabotan rumah tangga.

Pergeseran okupasi ini tentu saja membawa konsekuensi terjadinya pergeseran struktur sosial ke sistem yang lebih luas dari sekadar pertanian. Perubahan tersebut terjadi melalui jalinan hubungan sosial melalui sistem kelembagaan sosial yaitu kelembagaan hubungan kerja agraris berdasarkan kekuasaan tanah tidak lagi menjadi faktor yang determinan.

\section{Faktor yang Menjadi Dasar Dipilihnya Srengseng Sawah sebagai Perkampungan Budaya Betawi}

Pasca kepemimpinan Ali Sadikin. Pada saat Soeprapto menjadi Gubernur DKI perhatian terhadap Condet tak sebesar pendahulunya. Bahkan, boleh dibilang Condet nyaris terabaikan. Paling tidak, ini diungkapkan oleh Haji Mat Zakap, salah satu tokoh masyarakat Condet yang cukup disegani dan dihormati oleh warga Condet. Pria yang pernah diundang ke Thailand karena dianggap berhasil menggerakkan petani buahbuahan di Condet itu merasa kecewa dengan kepemimpinan Gubernur Soeprapto yang kurang perhatian terhadap masyarakat Condet. Kekecewaan ini sangat beralasan mengingat pada saat Condet ditetapkan sebagai cagar budaya, 
Haji Mat Zakap adalah sebagai penggerak dalam pengembangan budaya Betawi dan pertanian buah-buahan di Condet. Paling tidak apa yang dikeluhkan oleh Haji Mat Zakap merupakan representasi masyarakat Condet yang sudah dengan susah payah berpartisipasi dalam membangun Condet sebagai cagar budaya. Hal ini pula yang dapat menjelaskan bahwa partisipasi sosial masyarakat di Condet berlangsung secara bottom up untuk mengembangkan lingkungannya.

Gagal menjadikan Condet sebagai cagar budaya Betawi, Pemerintah DKI Jakarta merasa berkepentingan untuk memiliki kawasan pelestarian budaya Betawi. Ide ini awalnya berasal dari arahan Pemprov DKI Jakarta pada tahun 1996 agar ada asset wisata di Jakarta Selatan yang dapat dimaksimalkan. Pada 13 September 1997 diselenggarakan Festival Setu Babakan sebagai cikal bakal penentuan Setu Babakan sebagai Perkampungan Budaya Betawi (PBB). Dari lima lokasi yang telah disurvei yaitu Marunda (Jakarta Utara), Kemayoran (Jakarta Pusat), Condet (Jakarta Timur), Srengseng (Jakarta Barat), dan Srengseng Sawah (Jakarta Selatan), akhirnya pilihan jatuh ke Srengseng Sawah, Jakarta Selatan.

Alasan dipilihnya Srengseng Sawah sebagai PBB antara lain karena dianggap lingkungannya masih sesuai dengan karakter kehidupan masyarakat Betawi, keasrian adat maupun tradisi Betawi. Keberadaan Srengseng Sawah dipilih sebagai PBB tidak dalam waktu singkat, puncaknya dilakukan ketika Gubernur DKI Jakarta Sutiyoso mengajukan Rancangan Peraturan Daerah (Raperda) mengenai PBB untuk Kawasan Srengseng Sawah, Jakarta Selatan. Draf Raperda tersebut diajukan pada awal Februari 2005, setelah melalui perjalanan panjang, akhirnya Raperda tersebut ditetapkan sebagai Perda pada 10 Maret 2005. Perda tersebut sekaligus mencabut status Condet sebagai cagar budaya dan cagar buah-buahan.

Di atas tanah seluas 289 hektar, semua bangunan baik rumah, toko, maupun perkantoran yang ada di Kawasan Srengseng Sawah, ditetapkan harus bercorak Betawi. Kawasan Srengseng Sawah sejak awal tahun 1980-an banyak mengalami perkembangan khususnya sejak beberapa kampus berdiri, seperti Institut
Sains Teknologi Nasional (ISTN), Universitas Pancasila, Institut Ilmu Sosial dan Ilmu Politik (IISIP), Akademi Pimpinan Perusahaan (APP) maupun Universitas Indonesia (UI). Di lokasi PBB, Srengseng Sawah terdapat sebuah danau yang disebut 'Setu Babakan'.

Menurut Indra Sutisna, Sekretaris Pengelola PBB mengatakan dipilihnya Srengseng Sawah sebagai cagar budaya bertujuan untuk melestarikan dan mengembangkan budaya Betawi secara keseluruhan. Selain itu, di luar unsur pariwisata dan budaya Srengseng Sawah juga berfungsi sebagai pelestarian resapan air, dan mengembangkan nilai pendidikan. Salah satu perbedaan mendasar PBB di Condet dengan Srengseng Sawah adalah pengelolaan PBB Srengseng Sawah dilakukan secara terpadu, sementara di Condet kurang terpadu.

Pada saat ini PBB di Srengseng Sawah dikelola oleh sebuah tim yang bernama Tim Pengelola Perkampungan Budaya Betawi yang terdiri atas 30 orang. Tim ini terdiri atas unsur masyarakat dan pemerintah yang dibentuk sejak tahun 2002. Pemeliharaan sehari-hari perkampungan budaya Setu Babakan ditangani oleh tim pengelola. Tetapi, tim itu hanya bertugas melakukan pemeliharaan harian, dan tidak berwenang menetapkan program. Sementara itu, Dinas-Dinas yang terkait dalam penetapan kebijakan pengembangan perkampungan budaya itu sangat banyak, lebih dari 20 unit kerja. Soal taman, ditangani Dinas Pertamanan. Rumah adat, ditangani Dinas Perumahan. Pembinaan pedagang dodol dan bir pletok, misalnya, ditangani Dinas Perindustrian.

PBB Srengseng Sawah terdiri atas empat komponen utama yaitu panggung, pintu gerbang, rumah adat dan wisma. Pada tahun 2002, sebanyak 67 rumah warga Srengseng Sawah mendapat subsidi pembangunan dari pemerintah untuk memugar rumahnya dengan menggunakan arsitektur Betawi. Setiap sabtu dan minggu, di panggung berarsitektur Betawi yang dibikin oleh Tim PPBB sudah rutin berlangsung atraksi wisata seperti tari ondel-ondel, upacara adat perkawinan, khitanan. Turis mancanegara banyak yang mengunjungi lokasi ini.

Srengseng Sawah masih memiliki budaya Betawi sebagai ciri khasnya. Hal tersebut ditandai 
dengan masih bertahannya rumah-rumah panggung berarsitektur khas Betawi. Selain itu, masih bertahan juga makanan khas maupun aksesoris khas Betawi. Srengseng Sawah juga sangat potensial untuk mengembangan pariwisata budaya. Hal ini berkaitan dengan rencana pengembangan budaya Betawi sebagai komoditi pariwisata dalam kemasan perkampungan yang menarik bukan saja bagi masyarakat lokal tetapi juga bagi masyarakat di luar lingkungan etnis Betawi. Setiap rumah di perkampungan budaya itu juga akan disulap menjadi home stay. Pengunjung boleh menginap di rumah-rumah penduduk. Dengan demikian, para wisatawan bisa menyaksikan dari dekat budaya masyarakat Betawi. Menurut Indra Sutisna, informan yang diwawancarai menjelaskan ide awalnya semua orang yang belajar seni Betawi di Srengseng Sawah bisa tidur di rumah khas Betawi yang ada di situ. Ia menjelaskan:

"Mereka bisa makan masakan khas Betawi, membeli cendera mata dari rumah-rumah penduduk di situ, menyaksikan upacara adat, pokoknya semua di situ."

Dua tahun setelah Srengseng Sawah ditetapkan sebagai perkampungan budaya Betawi, wisatawan yang mengunjungi Srengseng Sawah cukup meningkat. Berdasarkan data yang didapatkan dari Indra Sutisna pada akhir minggu jumlah wisatawan bisa mencapai 300 orang. Sedangkan di saat diselenggarakan pertunjukan budaya, seperti pementasan lenong, jumlah pengunjung bisa mencapai 1.500 orang.

\section{Simpulan dan Saran \\ Simpulan}

Perubahan sosial yang terjadi di Condet yang kemudian mengakibatkan dipindahkannya perkampungan budaya Betawi dapat ditelusuri sejak kehadiran warga keturunan Arab dari Pekojan. Pada saat warga keturunan Arab dari Pekojan, Jambora, Jakarta Barat hijrah ke kawasan Condet untuk mengembangkan bisnis PJTKI banyak menimbulkan berbagai perubahan dalam bidang ekonomi, sosial, budaya. Perubahan yang signifikan adalah terjadinya pergeseran okupasi di luar sektor pertanian (off farm), yaitu sektor jasa seperti bisnis kontrakan, membuka warung makan, warung kelontong, karyawan, tukang ojek. Perubahan juga terjadi secara ekologis, yaitu tercemarnya kali Ciliwung akibat menumpuknya sampah-sampah terutama sampah plastik. Hal ini dikarenakan berdirinya pabrik plastik di kawasan Condet. Selain itu, karena semakin padatnya pemukiman di daerah Condet baik rumah penduduk maupun gedung-gedung perkantoran yang akibatnya menjadikan iklim dan hawa Condet tak lagi sejuk seperti tahun 1980-an.

Dipindahkannya pusat perkampungan budaya Betawi dari Condet ke Srengseng Sawah juga tak dapat dipisahkan dari struktur politik Jakarta dibawah Penetapan kepemimpinan Gubernur. Perhatian gubernur setelah era Ali Sadikin tidak lagi memusatkan perhatiannya pada pengembangan Condet. Srengseng Sawah dipilih sebagai pusat perkampungan budaya Betawi karena beberapa hal, yaitu: 1) daerah ini merupakan kawasan yang masih terjaga lingkungannya, yaitu lingkungan yang sejuk, asri dan cukup rindang dengan pepohonan; 2) Srengseng Sawah masih memiliki budaya Betawi sebagai ciri khasnya. Hal tersebut ditandai dengan masih bertahannya rumah-rumah panggung berarsitektur khas Betawi. Selain itu, masih bertahan juga makanan khas maupun aksesoris khas Betawi; 3) Dipilinnya Srengseng Sawah karena di daerah ini sangat potensial untuk mengembangan pariwisata budaya. Hal ini berkaitan dengan rencana pengembangan budaya Betawi sebagai komoditi pariwisata dalam kemasan perkampungan yang menarik bukan saja bagi masyarakat lokal tetapi juga bagi masyarakat di luar lingkungan etnis Betawi.

\section{Saran}

Srengseng Sawah sebagai PBB harus berkaca dari kegagalan Condet. Oleh karena itu, mengembangkan berbagai macam pendekatan partisipatoris dari masyarakat untuk terlibat aktif dalam melestarikan dan mengembangkan Srengseng Sawah sebagai PBB. Sedapat mungkin, orientasi pembangunan yang top down dalam pengembangan Condet dikurangi. Pendekatan bottom up perlu dilakukan karena dengan pendekatan ini akan dapat meningkatkan rasa memiliki dan lebih aware tentang Setu Babakan.

Dalam pengembangannya, pusat perkampungan budaya Betawi tidak bisa hanya 
mengandalkan Pemda DKI Jakarta tetapi dapat melibatkan pemangku kepentingan lain diantaranya pihak swasta, universitas maupun media massa. Pihak swasta sebisa mungkin harus sering dilibatkan dengan berbagai kegiatan dan program yang dimiliki PBB Srengseng Sawah. Pihak universitas dapat dilibatkan dalam kegiatankegiatan penelitian maupun pengabdian masyarakat. Dalam bidang penelitian, pihak universitas dapat dilibatkan untuk melakukan penelitian yang dapat memberikan berbagai rekomendasi dan masukan terhadap pengem- bangan PBB Srengseng Sawah. Tidak kalah pentingnya juga adalah media massa yang dapat mempublikasikan berbagai kegiatan dan program yang dilakukan sehingga gaungnnya semakin lebih terpublikasikan baik di tingkat nasional maupun intenasional. Dengan demikian, diharapkan, Srengseng Sawah menjadi ikon dan kebanggaan bukan hanya komunitas Betawi tetapi juga kebanggaan nasional yang dapat mengharumkan nama baik Indonesia.

\section{Pustaka Acuan}

Alamsyah P, Suwardi, Agus Heryana, Ria Intani, Endang Supriatna, Nina Merlina, T. Dibyo Harsono. 2004. Fungsi Keluarga dalam Penanaman Nilai-Nilai Pada Masyarakat Betawi di DKI Jakarta (Jakarta:Kementerian Kebudayaan dan Pariwisata).

Evers, Hans Dieter. 1986. Sosiologi Perkotaan;Urbanisasi dan Sengketa Tanah di Indonesia dan Malaysia (Jakarta:LP3ES)

Herlambang, Soerjono. 2006. Kisah Lapangan Monas, Politik Kota dan Hak Atas Kota dalam Chris Verdiansyah. 2006. Politik Kota dan Hak Warga Kota;Masalah Keseharian Kota Kita (Jakarta:Penerbit Buku Kompas)

Instruksi Gubernur DKI Jakarta Nomor 323 Tahun 1985 tentang Penyusunan Konsep Pelaksanaan Daerah Condet sebagai Daerah Buah-Buahan

Instruksi Gubernur DKI Jakarta No. 19 Tahun 1986 tentang Status Quo Pengembangan Kawasan Condet.

Instruksi Gubernur DKI Jakarta No. 227 Tahun 1986 tentang Pencabutan Status Quo Pengembangan Kawasan Condet.

Jary, David and Julia Jary. 1991. The Harper Collins Dictionary Sociology. (New York:Harper Collins Publisher).

Jellinek, Lea 1984. Seperti Roda Berputar;Perubahan Sosial Sebuah Kampung di Jakarta (Jakarta:Penerbit LP3ES)

Koentjaraningrat. 1997. Pengantar Antropologi I. (Jakarta : PT. Rhineka Cipta)

Manning, Chris dan Effendi, Noer Tadjuddin. 1996. Urbanisasi, Pengangguran, dan Sektor Informal di Kota (Jakarta:Yayasan Obor Indonesia)

McGee, T.G. 1971. The Urbanization Process in The Third World (London:G Belll and Sons, Ltd).

Nas, PJM. 1979. Kota di Dunia Ketiga ; Pengantar Sosiologi Kota dalam Tiga Bagian (Jakarta:Bhratara Karya Aksara)

Neuman, Lawrence. 1994. Social Researchs Methods:Qualitative and Quantitative Approaches.

(Boston:Allyn and Bacon).

Peraturan Daerah DKI Nomor 3 Tahun 2005 Tentang Penetapan Perkampungan Budaya Betawi di Kelurahan Srengseng Sawah, Kecamatan Jagakarsa, Kotamadya Jakarta Selatan

Raharjo, 1983. Perkembangan Kota dan Permasalahannya. (Jakarta:PT Bina Aksara).

Ramelan, Ran. 1977. Condet Cagar Budaya Betawi, (Jakarta:Penerbit Lembaga Kebudayaan Betawi)

Saidi, Ridwan. 1996. Demokrasi dalam Perspektif Budaya Betawi dalam Najib, Muhammad, dkk (1996). Demokrasi dalam Perspektif Budaya Nusantara (Yogyakarta:Penerbit LKPSM)

Saifuddin, Ahmad Fedyani. 2006. Antropologi Kontemporer: Suatu Pengantar Kritis Mengenai Paradigma. (Jakarta:Penerbit Kencana)

Saunders, Peter. 1989. Social Theory and the Urban Question. (London:Unwin Hyman) 
Schwab, William A., 1992. The Sociology of Cities, (New Jersey: Prentice Hall)

Shahab, Yasmine Zaki. 1994. The Creation of Ethnic Tradition ; The Betawi of Jakarta (London:School of Oriental and African Studies)

Smith, Michael Peter dan Joe R. Feagin (ed). 1987. The Capitalist City. (Oxford-Cambridge:Blackwell Publishing)

Soekanto, Soerjono. 2002. Sosiologi Suatu Pengantar. (Jakarta:Penerbit Rajawali Pers).

Sunarto, Kamanto. 2000. Pengantar Sosiologi Edisi Kedua. (Jakarta:Penerbit LP FE UI).

Syuaib M, Fauzie. 1996. Demokrasi dalam Perspektif Budaya Betawi dalam Najib, Muhammad, dkk (1996). Demokrasi dalam Perspektif Budaya Nusantara (Yogyakarta:Penerbit LKPSM).

Sztompka, Piotr.2005. Sosiologi Perubahan Sosial (Terjemahan Alimandan), (Jakarta: Penerbit Prenada).

Surjomihardjo, Abdurachman.1973. Perkembangan Kota Jakarta (Jakarta: Dinas Museum dan Sejarah DKI)

Susser, Ida (ed). 2002. The Castells Reader on Cities Social Theory. (Oxford:Blackwell Publishing).

Surat Keputusan (SK) Gubernur No D. IV-1511/e/3/74 tanggal 30 April 1974 tentang Penetapan Condet sebagai Pengembangan Kawasan Budaya Betawi.

Surat Keputusan Gubernur No D.I-7903/a/30/75 tanggal 18 Desember 1975, tentang Penetapan Condet sebagai Daerah Buah-buahan.

Travers. 2001.Qualitative Researchs Through Case Studies.(London:Sage Publications). 